\title{
The Unnecessary Nudge: Education and Poverty Policy in a Cairo Slum ${ }^{1}$
}

\author{
Heba Gowayed $^{2}$
}

\begin{abstract}
Drawing on data collected from 2008 to 2013 in a low-income Cairo neighborhood, this article examines the impact of a poverty alleviation program, a conditional cash transfer (CCT) that attempted to incentivize poor mothers, through a direct cash transfer, to send their children to school. The program met its goal. The mothers did send their children to school. I argue that only observing this outcome of school access, however, black-boxes the causal pathway of how mothers sent their children to school in the Egyptian context, and how the program mattered. Public schools in Egypt are free on paper but expensive in practice due to an informal system of "private lesson" and "study group" fees imposed by teachers. Mothers had always managed this expense, using scarce gendered household resources, before, during, and after the program. Through ethnographic, interview, and survey data, this article shows that while the cash-transferred to the mothers and labeled for education - enabled the mothers to send their children to school, the program conditions were unnecessary. The mothers did not need to be nudged to send their children to school. This Egyptian case study has implications for the use of behavioral incentives and for the importance of qualitative methods to the study of policy impacts.
\end{abstract}

KEYWORDS: conditional cash transfer; education policy; family; impact evaluations; incentives; relational work.

\section{INTRODUCTION}

Programs that attempt to nudge the poor to behave differently have proliferated as a development strategy (Bertrand, Mullainathan, and Shafir 2004; Grant 2011; Thaler and Sunstein 2009). Emerging from behavioral economics, these programs assume that individuals are not completely rational and need to be pushed by policy makers to behave in ways that are more "optimal" (Fiszbein and Schady 2009). One group of programs that has taken this approach, conditional cash transfers (CCT), has been widely implemented across low- and middle-income countries (Baird et al. 2014; Galiani and McEwan 2013; Lomelí 2008). CCTs transfer cash to reduce short-term poverty, contingent on recipients' fulfillment of conditions regarding child health and education (Lomelí 2008). These programs assume specifically that parents are "myopic" or have "incomplete altruism"- that is, are not

1 The author would like to thank the team at the American University in Cairo where she began this work as a researcher in 2008. The team was led by Hania Sholkamy and included Lenka Benova and Mohamed Hassan. The author's argument, however, is her own and does not represent that of the team. The author would also like to thank Viviana Zelizer, Mitchell Duneier, Alejandro Portes, and Nicholas Occhiuto for reading many drafts of this work. Finally, thank you to the Center for the Study of Social Organization at Princeton University for supporting this research and to its members for providing feedback on early drafts.

2 Department of Sociology Princeton University 106 Wallace Hall, Princeton, New Jersey 08544; e-mail: gowayed@princeton.edu. 
behaving in the best interest of their children - and need to be incentivized to make human capital investments in their children, to make decisions that are "privately" and "socially optimal" (Fiszbein and Schady 2009).

In this article, I examine a CCT program implemented in a low-income Egyptian neighborhood between 2009 and 2011 that incentivized poor mothers through a direct cash transfer to send their children to school. The program met its goal. The mothers did send their children to school. As a result, a policy evaluator looking exclusively at the CCT program's schooling outcomes in this neighborhood may conclude that the CCTs worked in changing the behavior of the poor. Drawing on ethnographic, interview, and survey data, I argue that the CCT worked in unanticipated ways. Rather than incentivizing mothers to change their behavior, the CCT became an additional tool in mothers' strategies to confront this expense. This case study, an exploration of how a CCT program mattered in the lives of low-income Egyptian mothers trying to educate their children, has broader implications for how we should observe cash incentives and how we should understand program impacts.

In the case of Egypt, public education is a low-quality institution, or one that does not work as its blueprints dictate it should (Portes and Smith 2012). While the Egyptian constitution mandates free and quality education for children through the 12th grade, low teacher salaries have resulted in the creation and normalization of an informal and corrupt system of teachers coercing parents to pay fees in the form of "study groups and private lessons" (Elbadawy 2015; Sobhy 2012; Tadros 2006). Unable to contest these payments, parents comply with teacher demands in an attempt to facilitate their children's access to education or their ability to learn (UNESCO 2005). By some estimates, through this informal system, parents match dollar for dollar what the Egyptian government pays on their students (Fahim and Sami 2010). Importantly, the burden of this Egyptian low-quality institution has become a poor person's burden, because the nonpoor have been sending their children into the expanding private education system (Ille 2015; Tadros 2006). Thus, despite the formal mandate, public schools are not only not free, but for the poor, they are also expensive. Moreover, the quality of the education is poor. Cognitive and test scores lag behind other countries, and the quality of the educational system has been ranked worse in the world by the World Economic Forum (Hanushek and Wößmann 2007; Olson et al. 2007; Schwab 2014).

In the case of this urban slum, the burden of child access to school is shouldered by low-income mothers. By examining the experience of mothers before, during, and after the CCT program, I challenge the behavioral assumptions implicit in the program. I take a relational approach, which sees the economic decisions of individuals as emerging from their interpersonal relationships and shared cultural meanings (Zelizer 2012). Here, the economic decisions of mothers concerning child education is a function of their relationship with the state that has de facto stripped their children of free education, the value mothers assign to education, and household inequalities that inform how resources are distributed and negotiated by gender. Using this approach, I show that women highly valued child education, so much so that they did the difficult work of putting together scarce resources to manage these fees. Given the fees associated, it is this commitment and work that is the reason why their children access education-before, during, and after the CCT. 
Viewing the program within the broader context of mothers' work, it is clear that the incentives were unnecessary. It was the cash, transferred directly to women, and safeguarded under the label of a child education program, that facilitated women's ability to send their children to school when it was available. For this reason, I argue that the program's impacts were not what they seem.

This article proceeds as follows. First, I examine literature on CCTs and impact evaluations, and then a literature on how the poor manage their poverty, introducing my approach to each. Second, I provide background on the quality of Egypt's educational system. After a discussion of methods, I present the results of the study, clarifying why and how mothers managed to send their children to school with and without the CCT. Finally, I offer concluding remarks on the danger of deducing program effectiveness from quantitative impacts alone and on the broader implications for CCTs.

\section{LITERATURE REVIEW}

\section{CCTs and Impacts}

Beginning in Latin America in the late 1990s, CCTs have been broadly applied around the world, moving into Africa and parts of Asia in the 2000s, and were even implemented with low-income families in New York in 2007 (Baird et al. 2014; Lomelí 2008; Riccio et al. 2013). Experiments have shown, overall, that CCTs have had positive average impacts on access to schooling and health care (Baird et al. 2012). However, more recent studies have nuanced these results, focusing on three issues: the utility of conditions over cash, to whom the cash is targeted, and the quality of institutions.

First, experiments that have tested whether cash or conditions matter for impacts have had mixed findings. While the CCT was more effective for marginalized girls in Burkina Faso as compared to the unconditional cash transfer (UCT) (Akresh et al. 2013), it had a negative impact on marginalized girls in Malawi who were unable to comply with conditions, dropped out, and saw a spike in HIV (Baird et al. 2012). The varying outcomes across these studies speak to how the impacts of development strategies are filtered through local context and mediated by aspects of beneficiary lives (Rodrik 2008). Importantly, in Morocco, researchers nuanced the cash versus conditions dichotomy to test whether a "label" of the cash as intended for child education would be sufficient to achieve intended outcomes (Benhassine et al. 2013). Comparing labels to conditions, they found that conditions did not seem to matter for child school attendance. While this finding seems innocuous, monitoring is expensive. If incentives and conditions are unnecessary, then they are using up resources that could be used for other development outcomes (Lomelí 2008).

Second, in terms of targeting, this same pilot tested whether the gender of the transfer recipients mattered. Most CCTs target mothers who are assumed to be more likely to spend on children, and as a way to "empower" them, though critics argue that these programs put mothers to work for development (Adato and Hoddinott 2007; Molyneux 2006). The Moroccan program, testing this, did not find a difference between cash transferred to either parent (Benhassine et al. 2013). 
However, this program, lacking a qualitative component, did not clarify why the label was effective, or why fathers and mothers behaved similarly.

Finally, a third set of studies looked to context, pointing out the crucial place of institutions in facilitating or hindering CCT impacts (Handa and Davis 2006). For instance, in Colombia, the CCT had positive impacts on rural children's schooling up to 12 years old but negative impact on urban children (Garcia and Hill 2010). Although the authors suggested that one explanation could be value assigned to child labor in each context, another possible explanation could also be variation in the supply side, which saw no increased support despite increased demand compelled by the program. In Brazil, evaluators report that supply-side constraints continued to be the main obstacle to wider benefits (Soares, Ribas, and Osório 2010). Review studies question what impacts these programs will be able to have on longterm poverty given variation in the quality of services across countries (Lomelí 2008). Moreover, given finite resources, demand-side interventions may detract investment from supply-side reform (Handa and Davis 2006).

I contribute to these conversations around CCTs through a qualitative questioning of the necessity of conditions in the Egyptian case, a focus on the role of mothers and on the quality of the institutions that recipients are incentivized to access. In doing so, I contribute to methodological approaches to impact evaluation. While most of the studies cited above use the "gold standard" of experimental trials, even the most robust design can only observe average impact (i.e., whether cash or conditions matter for a given outcome). In their focus on impacts, these approaches black-box causal pathways (Gertler et al. 2011). If the expected impact is achieved and children go to school, then the program is considered successful. However, causal mechanisms or the process by which a treatment shapes an outcome is more complex in field studies (Imai, Tingley, and Yamamoto 2013). As alluded to in the cited impact evaluations of CCTs, whether a program is successful involves mediating variables, such as cultural schema concerning education, the nature of the institutions that surround the households, or intrafamily power dynamics. Like other quantitative projects of commensurability, large-scale studies obscure these qualitative complexities of respondent lives for the sake of measurement (Espeland and Stevens 1998). While mixed-methods studies are identified as "best practices," qualitative studies do not always accompany impact evaluations; when they do, they are tangential, poorly funded, and often not inductive, seeing recipient lives with a narrow focus on expected impacts (Adato 2008). Here, through a qualitative focus on process, I examine not only the role of conditions and institutions but also whether labels on cash matter and whether it matters that the program transfers cash to women. I demonstrate in this article that impacts alone can tell a dangerously lacking story, particularly when beneficiaries are managing household power dynamics and informal systems that more than rarely plague the poor in low-income countries.

\section{How the Poor Manage}

To understand how mothers managed the cost of child education, I turn to literature that theorizes how the poor manage their poverty. In economics, there are 
two competing views. There is a behavioral approach that understands individuals as behaving irrationally under constraint and in need of being pushed toward optimal decisions (Kahneman 1994; Thaler 1999). Poverty alleviation projects taking on the behavioral approach, such as CCTs, assume that incentivizing individuals to behave differently is a solution for poverty (Bertrand et al. 2004; Fiszbein and Schady 2009; Thaler and Sunstein 2009). Challenging this approach are development economists, Collins et al. (2009), who take a neoclassical view. In their study, they show through an analysis of the daily accounts of those living under $\$ 2$ a day that the poor, like others, are rational actors who determine what is beneficial for themselves, manage irregular incomes creatively, and treat cash as fungible. Rather than change the behavior of the poor, poverty alleviation programs, they contend, would diversify the tools at their disposal, such as access to microcredit or unconditional cash.

The drawback to both of these approaches, however, is their methodological individualism. The behavioral approach privileges psychological explanations to structural ones in understanding how the poor manage poverty. And while the cited work from development economics provides valuable empirics on the strategies of the poor, by viewing cash as entirely fungible they do not take into account how intrahousehold power, or the cultural value of certain expenditures, informs economic decision making in low-income households, and how resources are used. To capture these economic decisions, this article uses a third approach, a relational approach, from economic sociology (Zelizer 2012). Rather than focusing on the individual, the approach foregrounds connections between individuals, and meanings held by individuals, as informing transactions. Finding matches between individuals" social relationships and "fitting" economic transactions is "relational work" (Bandelj 2012; Zelizer 2012). This approach allows for an observation of how citizen disenfranchisement and household inequalities shape economic decision making in these households in ways that are not possible through the other approaches.

Studies have not extensively used relational approaches to explore inequality (Bandelj 2012). However, this approach provides three tools that are useful for observing how inequalities that inform poverty also shape its management. First, paying attention to explanations of why an individual says she acts the way she does clarifies both what she values, and the extent to which she feels she has agency in a given transaction (Tilly 2006). Second, and related, while relational work is reciprocal, it need not be equal (Bandelj 2012). Who does what in the negotiation-holds fast, compromises, barters, begs - clarifies who has the power in a relationship, which clarifies the relationship between mothers and teachers. Third, particularly in the context of scarcity, money is not fungible in households. Instead, people earmark cash amounts for different expenditures. Earmarks are shaped by how the money was earned, as well as by which outcomes are valued, and who else is contesting that money (Zelizer 1996, 1997, 2012). Attention to earmarking clarifies that despite mothers' commitment to education, the label on the cash transfer as "for education" and its transfer specifically to mothers shapes how mothers can use this cash. It helps mothers safeguard this cash for education that they value, despite competing household demands and unequal distribution of resources within the 
household. In this way, using the relational approach clarifies the cost of education on families, how they manage it, why they manage it, and how the CCT mattered to this management.

\section{Background: Low-Quality Egyptian Education}

Egypt's schools are low quality; they do not work the way they should on paper (Portes and Smith 2012). They feature crowded classrooms and limited facilities (Herrera 2003; Loveluck 2012; Sobhy 2012; Tadros 2006), and in-class instruction is poor (Handoussa 2010; Ille 2015). As a result, children in Egypt's public schools score low on tests examining cognitive ability and math knowledge (Hanushek and Wößmann 2007; Olson et al. 2007) and lack relevant skills for the labor market (Assaad and Roudi-Fahimi 2007).

What explains the low quality of Egyptian public education? One explanation is the educational system's massification (Post 1981). In the Egyptian case, a commitment to free education through college for all Egyptians, introduced in the Nasserist Arab Socialist era, remains morally significant (Hoodfar 1997; Rutherford 2008; Singerman 1995). As a result, gross enrollment rate in primary school rose from $64 \%$ in 1970 to $98 \%$ in 2014 (World Bank 2015). Over this same period, the quality of educational services declined, leading to the current situation (Tadros 2006). Massification alone is an insufficient explanation, however, as it was the combination of massification with a reduction in funding and otherwise unresponsive policies that amounted to decline (Herrera 1992; Mitchell 2002). In the Egyptian case, economic restructuring, in response to World Bank and International Monetary Fund pressure to reduce Egypt's levels of inflation, led to reduced expenditure on the public sector (Weinbaum 1985). This reduced expenditure resulted in the declining wages of teachers to poverty wages (Rashwan 2011; Tadros 2006). However, the Nasser-era practices of promoting teachers based on years served, rather than on merit, remained (Tadros 2006). This, coupled with a lack of accountability due to the authoritarian political system, led to the emergence of a parallel, corrupt system of teachers eliciting payments from parents (Herrera and Torres 2006; Kandil 2011). This system is comprised of two types of payments: for "private lessons"-after-school instruction to small groups of students-and "study groups" or in-school tutoring by the classroom teacher.

Mariz Tadros (2006) describes the emergence of these fees. First, teachers gave private lessons to wealthy students. But as teacher salaries continued to decline in the 1980s, in the context of restructuring, this practice trickled down to the poor. By the late 1990s, the Ministry of Education introduced study groups as an attempt to stop the practice of private lessons. Study groups were meant to be a low-cost, voluntary, after-school assistance. In practice, they became expensive, mandatory in-school sessions. Administrators at schools received a cut of the study group fees $(15 \%)$, furthering bureaucratic complicity. As a result, teachers and administrators threaten students with failure and remove students from classrooms if they do not pay for study groups. There are also documented cases of corporal punishment by teachers for student nonpayment (Sobhy 2012; Tadros 2006). 
In an example of a global phenomenon, where informal systems emerge when formal systems fail, teachers in the Egyptian case use public office for private gains (Balabanova and McKee 2002). Moreover, as a result of this system, teachers have limited incentive to teach in the classroom (Assaad 2006; Assaad and Krafft 2015; Sobhy 2012). Because teachers demand payment and because they do not teach in classrooms, private lessons and study groups are not voluntary extra help. Both have an element of coercion as the products of a system that has failed students. Still, study groups are effectively the cost of sitting in the classroom and do not ensure that a child will benefit from instruction. The more expensive private lessons, by contrast, give more of a possibility for learning (Sobhy 2012; UNESCO 2005). However, studies that have examined private lessons' effect on learning have questioned whether their impact is the result of endogeneity - that is, children whose parents pay were more likely to do better for other reasons (Elbadawy 2013). This study describes the work that goes into managing this informal, corrupt system by low-income mothers, and how the CCT factored into that work. First, the following section outlines this study's methodology.

\section{DATA AND METHODS}

\section{Research Sample and the CCT}

This article draws on ethnographic, interview, and survey data collected from low-income mothers in the Cairo neighborhood of Ain EsSira. Ain EsSira was the site of the Egyptian government's CCT program pilot from 2009 to 2011. The Egyptian Ministry of Social Solidarity funded and staffed the CCT implemented in this neighborhood. A team at the American University in Cairo provided technical support. Following international best practices, the program selected, as recipients of the CCT, mothers who had children under the age of 18 , lived in crowded quarters of more than three to a room, and had to deal with chronic health burdens within their households, as do $61 \%$ of all Ain EsSira residents (Handoussa 2008; Lomelí 2008). This program transferred cash-250 EGP per month ${ }^{3}$ - to beneficiaries, in return for their fulfillment of conditions on child education (attendance $85 \%$ of the time) and preventive health.

\section{Data Collection}

The author, a native Arabic speaker, worked in Ain EsSira as a researcher on behalf of the program from 2008 to 2011. Her work entailed supporting focus group discussions among low-income mothers in Ain EsSira that informed the program's design, following up with the 162 mothers selected as the beneficiaries of the CCT, maintaining contact with the ministry social workers, and supporting the designing and conducting of the questionnaires that the program used to monitor the progress of the families. The author returned to Ain EsSira in the summers of 2012 and

\footnotetext{
3 This amount was approximately 30\% higher than was being transferred under government welfare. It was meant to subsidize incomes, not bring recipients up to the poverty line alone.
} 
Table I. Study Sample 2008-2013

\begin{tabular}{llll}
\hline Type & \multicolumn{1}{c}{ Year } & Program Timing & Respondents \\
\hline Focus Groups & 2008 & Preintervention & 82 women, 14 men \\
Questionnaire 1 & 2009 & Intervention & 156 women \\
Questionnaire 2 & 2011 & Intervention & 145 women \\
Interviews & $2012-2013$ & Postintervention & 26 women \\
Field Observation & $2008-2011$ & Intervention & 156 women \\
Field Observation & 2013 & Postintervention & 5 women and families \\
Interviews & 2013 & Postintervention & 4 teachers \\
\hline
\end{tabular}

2013, as an independent researcher. During this time, she conducted interviews after the program's cessation with former beneficiaries and field observations (Table I).

Focus Group Discussions Eight focus group discussions with women $(\mathrm{n}=82)$ and two with men $(n=14)$ were conducted prior to the launch of the project in 2008 . These discussions asked questions that concentrated on families' economic burdens, issues of child educational access, access to health care, and women's work. The author was present for the focus group discussions with women, taking notes. The author listened to the men's focus groups and coded the transcript of the discussion specifically focusing on study groups, private lessons, and understandings of women's responsibilities. All coding for this project was conducted using NVivo qualitative software.

Questionnaires The author, along with two enumerators, conducted questionnaires in 2009 and 2011. Both questionnaires were administered to beneficiaries, who were women-due to the project's design. The first questionnaire was administered to 156 women and the second to 145 women. The difference in these two samples was due to the fact that some families moved, some women passed away, and some were removed from the program due to no longer having school-aged children. Importantly, no one was kicked out of the program due to noncompliance with its conditions. The questionnaires focused on family income and expenditure, the use of the program money, as well as women's well-being including experiences of debt, domestic violence, contraceptive use, and time use. The author kept qualitative notes on the interviews and entered the quantitative data into data analysis software for descriptive and analytical use.

Interviews At the time of the questionnaire implementation in 2011, the author randomly divided respondents between herself and the two hired enumerators. The author herself conducted the survey with 30 mothers in 2011. The author returned to those same families in 2012, as an independent researcher, for a semistructured follow-up interview. Of the 30 respondents, 26 were available and willing to participate. The author used a semistructured protocol to interview the mothers about how the (now former) participants of the CCT had experienced the revolution, how they felt about the CCT program, and how they currently fundraised for their children's education in its absence. Due to the author's history in the neighborhood, the respondents knew her, which facilitated the interaction and the request to record 
interviews, particularly in a postrevolutionary politically contentious environment. The interviews were transcribed and coded first inductively by the author and then specifically for educational issues.

In summer 2013, the author conducted interviews with experts from the leadership of the Egyptian Independent Teacher's Syndicate $(n=4)$ as a check on the statements of mothers (Duneier 2011). The author coded the audio of the interviews for how the respondents described this fee.

Field Observation The author maintained a regular field presence from 2008 to 2011. In 2012, the author conducted the interviews at the respondents' homes. In 2013, the author also returned to the field to tutor the children of one of the respondents-Om Ismail ${ }^{4}$ - and her neighbor, as well as to visit other women in the neighborhood. The author took field notes for the three days a week she visited the neighborhood over a six-week period during June and July 2013, which she coded.

\section{FINDINGS}

The results of this article are presented in four parts. First, I show that the educational expense was a burden on mothers before, during, and after the CCT program. Second, I consider the quality of the educational institution that mothers are incentivized to access on behalf of their children, highlighting their lack of power in relation to teachers. Third, I show that child education is primarily a mother's burden and examine why mothers value education, confronting the behavioral assumption held by CCTs. Finally, in the last empirical section, I examine the importance of the CCT cash in the context of household scarcity, and how the targeting of mothers and the labeling of cash as for education helped mothers protect this money from other demands.

\section{Enter the CCT}

The streets of Ain EsSira, a neighborhood in central Cairo, are always buzzing with children. One morning, a girl with a ponytail and wire-frame glasses, wearing a uniform and a SpongeBob backpack, walked to school holding her father's hand. Two blocks down were two boys, neither of whom was wearing uniforms, who laughed with a banana held up to their ear like a mobile phone. A few blocks farther were other boys, picking up trash from the discards of the tannery, which was both the economic hub of the neighborhood and a health hazard emitting toxic fumes.

Surrounding these children were the houses in which they lived. The less poor emerged from the remnants of the Egyptian government's first housing project in the 1960s, with ramshackle appendages tacked onto the original concrete block. The poorest emerged from the Iwaa, shacks built from salvaged material, erected originally by the Mubarak government as temporary shelter for people displaced from natural disasters and then forgotten. There were others who lived in the

${ }^{4}$ All names used in this article are pseudonyms. 
crudely constructed four- to five-story buildings directly around the tannery, which were subject to regular sewage flooding and patchwork electricity. And enclosing all of these homes was the historic Salahdin Aqueduct. One respondent wondered aloud why renovation always seemed to be happening to the facade of the ancient structure but never in the neighborhood contained within its walls.

Indeed, even though national gross school enrollment was high, for lowincome children, like those in Ain EsSira, self-reported child school attendance was low. ${ }^{5}$ According to the Egyptian Demographic Health Survey (DHS 2008), only $84 \%$ of Egyptian children in the bottom quintile attended primary school. Only $53 \%$ attended secondary education. These are compared to national averages of $90 \%$ for elementary school and $69 \%$ for middle school. While the designers of the CCT knew there was little that they could do for the children who had already dropped out - there were few remedial options - they designed the program to keep the currently enrolled in school and attending, assuming that the solution was to incentivize mothers to send their children to school.

In 2009, the program was launched. The major condition of the program was that children must attend school $85 \%$ of school days. If this condition was met, the family of the child would receive monthly cash assistance, disbursed to mothers, which was higher than any welfare payment that these families could secure. Each month, the cash was disbursed via a bank account-where mothers could keep and withdraw money (if they wanted to) but not deposit money. Mothers-previously entirely unbanked-withdrew the money from the ATM, having received training on how to use a PIN.

The program conditions were monitored by Ministry of Social Solidarity social workers, who communicated with mothers with the help of a calendar that hung in their apartments. Because many were illiterate, the mothers were taught to record the days that their children had gone to school using stickers. The social workers went to work each day in the neighborhood and made unplanned visits at least once a month, noticing if a child was at home multiple times, or if they saw them working nearby. According to self-reported attendance by mothers and the notes of the social workers, no child dropped out of school for the duration of the program.

One could interpret this impact to mean that the behavioral incentives worked, that these were the necessary nudge to bridge the gap between children and educational services. However, an observation of the lives of families tells a different story. It shows that mothers are committed to child education but lack the resources to send their children to school. Mothers are so committed that they cobble together disparate household resources to do so, despite other demands on household money. When children drop out, it is because of scarcity rather than mother's disinterest. While the CCT evaluation would argue that the conditions succeeded, I argue that the cash - disbursed to mothers and labeled for education —was the effective mechanism of the program.

\footnotetext{
5 I use this measure here rather than "enrollment" because it indicates whether parents perceive their children as "going to school" as the question is asked in Arabic. The DHS does not check school rosters, so this measure is fitting to this study which is interested in how parents self-report educating their children. Importantly, in 2014, numbers were lower, due in part to the political upheaval.
} 
In the case of Fadila, a 29-year-old mother of three school-aged children, who lived behind the vegetable stalls in the central market of Ain EsSira in a two-room house with six people, the program did not incentivize but enabled. During the program, she spent the money on her children's lessons. She explained:

\section{When I was receiving the money [the CCT], I was able to send both [sons] to private lessons, I didn't feel the burden. I would take the money right when it came straight from the bank to the schools, to pay the private lessons.}

Unlike other household resources, over which she fought with her husband, there was no negotiation on how this money would be spent. It was in her name and for school. She contrasted the period in which she had this cash to the burden she felt before and after the program, when she also struggled to send her children to school. She explained that after the program ended, she was less able to pay for private lessons and had to resort to study groups only (as opposed to study groups and private lessons), particularly for her younger son. Study groups did not offer the same quality of education as private lessons. She worried about what would happen when her seven-year-old daughter also began to demand expensive lessons. Indeed, placing this expense within the broader framework of Fadila's life, we can see why she struggled. Her husband was a day wage laborer, and she sold goods door to door, a local occupation called delala, but various illnesses made her work irregular. She was one victim of the very high chronic health burden in the neighborhood.

While Fadila had managed to keep her children in school prior to the CCT, Dina, a 46-year-old mother of three, could not keep her daughter, Maie, in school when her husband, who was a construction worker, was diagnosed with hepatitis $\mathrm{C}$. Maie, who was 13 at the time, is part of the national nonattendance statistic. When her husband fell ill, Dina found it hard to pay basic bills, in addition to her husband's medical expenses. She certainly could not afford Maie's lesson or study group fees. As a result, Maie stayed home and helped her mother take care of the household. However, Dina was eventually able to find a job as a janitor at a local school and was able as a result to keep her younger daughter, Sarah, in school. Sarah was 15 at the time when the CCT began, and Dina used the cash to pay for Sarah's very expensive technical high school lessons, which sometimes amounted to 400 EGP a month. After the program, Dina continued to pay for Sarah, who was about to graduate, as well as for her son who was 10. Maie, meanwhile, was getting married to a man who also had not completed high school. The variation in Dina's treatment of Maie and Sarah cannot be explained by a lack of commitment or a lack of value assigned to education but rather by a lack of resources.

Fadila and Dina are no exceptions to the pattern observed in this neighborhood, where low-income women face the expense of an educational system that does not offer free or quality services prior to, during, or after the CCT. Prior to the program, focus group discussions were held with eight groups of women across various nongovernmental organizations (NGOs) in Ain EsSira. Across all eight of these discussions, the women responded unanimously to the question "What is your biggest burden?" with "The cost of child education." During the CCT program, like Fadila and Dina, $77 \%$ of women reported spending the money predominantly on 
Table II. Children (6-18) in Study Groups and Private Lessons, from Interview Data, July 2012

Failure Ratio*

\begin{tabular}{lrc} 
At Least One Lesson & $21(35 \%)$ & 0 \\
Study Groups Only & $24(40 \%)$ & $1: 8$ \\
Neither & $8(13 \%)$ & $1: 4$ \\
Not in School & $7(11 \%)$ & - \\
Total & 60 & $1: 12$ \\
\hline
\end{tabular}

* Ratio of students who fail to those who pass by category.

the cost of child education, even though the program cash expenditure was not monitored. And after the CCT, $84 \%$ of mothers continued to report that they paid for their children to access study groups and private lessons (see Table II for breakdown of which services children were enrolled in). The majority of parents, from the poorest to the most educated in the sample (who had the equivalent of an associate' degree), paid these fees coerced by the teachers. The following sections address the nature of the educational system that compelled these fees, the value mothers placed on education that negates the need for behavioral incentives, and the ways that mothers cobbled together resources to confront this expense. I argue that these components together inform how children access school and why the CCT was successful.

\section{Fees as Fact}

While the CCT program assumes implicitly that the solution to child education is to nudge mothers, the quality of the Egyptian educational system creates an informal system with which mothers must contend. This system, its cost, and the lack of power that mothers have to confront it are key determinants of how children access school and why, sometimes, they do not.

To mothers, teachers are wrongdoers. From the teachers' perspective, however, there is a system of which they are the victims - a system of underpayment and overcrowding. One said,

\footnotetext{
How can I teach 80 kids? Even if God himself were to descend, he could not teach them all. They are meat on meat; if one wants to go to the bathroom, he has to climb on the desks of all the others to get out of the class. So what does the teacher do? He takes the ones who have paid for lessons and makes them sit in front, and only corrects their homework and teaches to them.
}

Another asked, "What can we do? We have to live."

Because of the opacity of this system and the lack of pathways that mothers have to confront teachers, mothers assume that teachers have more power than they do. They assume that they can fail students, even though grading occurs off the school premises in central locations. But teachers do have other control. They can kick a child out of class to prevent him or her from learning. And they can and do verbally intimidate children. ${ }^{6}$

\footnotetext{
${ }^{6}$ Tadros (2006) reports physical violence, although this was not observed in this study.
} 
Lacking a means to confront teachers in an authoritarian system, mothers had limited recourse. The weak party in the relational negotiation, mothers did the begging, citing their own poverty as a reason why they should not pay. As representatives of the public school of an authoritarian system, the teachers did not have to give an explanation for their actions or meet moral prescriptions.

Afifa was a widowed mother of a 14-year-old girl; she dutifully paid the regular monthly fee of 180 EGP for private lessons. One day, she received a call from her daughter's teacher, who happened to be proctoring her exam, asking for an additional half-month's pay for the exam period while there were no classes. When Afifa objected, the teacher threatened her. "He would not give me her exam entrance number unless I paid him another half month." He threatened to prevent her daughter from taking her exam at all. Afifa, who worked irregularly cleaning homes, went into debt to meet the teacher's request, unable to further advocate for her daughter.

Om Ismail, a mother of nine, six of whom are school aged, tried to beg the teacher to discount her fees. She told the teachers about her husband's diabetes and that she had nine kids. But these invocations were futile; she said, "I stopped explaining." Instead, she began to anticipate which teachers were the most ruthless. Who was most likely to insult her children or kick them out? Through this process, Om Ismail ensured she paid for study groups most of the time for most of her kids. However, she also inadvertently rewarded aggressive teacher behavior. Meanwhile, the study groups offered a poor level of education. While all of Om Ismail's children were passing English, none knew their ABCs, even those in middle school, as the author learned when she tutored them in Om Ismail's home.

Indeed, this system was particularly damaging when it resulted in children being kept from school entirely. There were those who kept just one child from school. Badreya, for instance, had a son in high school and a younger daughter. Her son had very expensive lessons and wanted to become an engineer. He had excellent grades. As a result, Badreya stopped paying for her daughter entirely. When I asked her why, she said she couldn't afford both and her daughter wasn't as invested.

The importance of girls' education was expressed in multiple women's responses. For instance, Gamalat, a mother of five girls, said, "Even if a child doesn't work with her degree, it's better than not knowing anything, like me. Especially if that child is a girl, then she must be educated three times over!" And this perspective bears out in some of the data. Girls and boys were almost as likely to receive private lessons ( $4 \%$ difference favoring boys). However, in all cases where parents had stopped paying for one child, that child was a girl. While national data showed that the gender of the child was typically not the main determinant of whether families paid for study groups or lessons (Assaad and El-Badawy 2007), the same data showed that in poor urban contexts, parents pay less for girls than for boys (Sayed Langsten 2014). Moreover, girls in this sample were significantly more likely to drop out of school than boys. ${ }^{7}$ This may be caused by the exceptional

\footnotetext{
7 Using one-tailed Barnard exact test at .05 level.
} 
scarcity faced by this sample-discussed in the final empirical section of this article - that sometimes overtakes intentions.

Finally, there were three mothers who refused to pay at all. Haneen, for instance, who sold intestines that she gathered from the slaughterhouse for a living, responded simply, "I cannot pay," to the question of why she does not. While her daughter dropped out of school in the third grade and now works as a janitor at a local NGO, 12-year-old Mohamed was enrolled. Haneen asked Mohamed, who was present in the apartment when the author visited, to recount what a typical day of school looked like for him. "I study my lessons in the courtyard because the teachers allow only those kids who take lessons and study groups to sit in the class." When Mohamed passed, Haneen was sure it was a mistake but chalked it off as the work of God: "His passing grades are from God, and they made me so happy... . God carried him through."

In these examples, there is a spectrum of strategies by which mothers managed the school system's poor quality and high cost. These cases demonstrate how mothers manage, or are defeated, by this system. The following section examines further mothers' role in management by looking at why they do this difficult work required to send their children to school.

\section{Valuing Education}

Charles Tilly (2006) argues that the reason individuals give for why they make decisions clarifies the nature of stratification in the relationships that scaffold economic ties and what people value. This article argues that the answers to the question of why mothers pay are (1) the division of labor within the household that makes child education their burden to bear, and (2) the value they place on this education. While the first answer speaks to the importance of targeting cash to mothers, the second further questions the program's behavioral assumptions, or the idea that mothers need to be incentivized to invest in their children's education.

First, fathers, like Moneer, a metal worker, who exclaimed in the focus group that "a father's responsibility is to educate his children," do care that their children are educated. However, both mothers and fathers described the work of overseeing child education as primarily a mother's role. Indeed, when fathers were asked in the focus group discussions to express their views on women's work, they stood firm that a mother was primarily responsible for rearing children. If she did work, they contended, it should not be at the expense of her "duties." One father reported that his wife's work was a problem for this reason.

This gendered division of labor that places mothers as caretakers is not surprising in the Egyptian context, where women disproportionately shoulder household obligations (England 2010; Hoodfar 1997). It is also not surprising that mothers take on additional financial roles as an extension of this caretaking responsibility, given that mothers are increasingly shouldering the responsibility for household poverty globally (Chant 2008). In a questionnaire conducted with the full sample of the CCT beneficiaries $(n=156)$ in $2009,79 \%$ of mothers reported that the responsibility for approaching their children's schools in case of a problem was primarily 
theirs, and $64 \%$ reported that it was primarily their responsibility to figure out how to raise funds for this expense. The rest managed this expense and school difficulties with help from their husbands.

The extent to which this fee is sometimes a mother's exclusive responsibility is apparent in the case of Om Ahmed. Om Ahmed got into a fight with her husband that ended in their separation and her return to her ancestral village in Upper Egypt. Later, after the couple reconciled their differences, Om Ahmed returned to Ain EsSira, only to find that her son had failed two classes. The child's father had not paid the fees for either private lesson or study group in her absence and had been inattentive to whether he was in school. It was thus incumbent on her to rectify the problem. To do this, she asked her sister-in-law to borrow 50 EGP. With the money, she bribed the janitor to both help her son with the Arabic language exam, as well as to act as an intermediary with the English teacher in order to convince him to help her son during the English exam. ${ }^{8}$ With her intervention, her son passed on to the next grade, an outcome improbable had she not returned.

Why are these mothers so committed to paying despite the unfairness of the educational system and intrahousehold compulsion? There were interconnected motivations. Mothers who educated their children were seen as "good mothers" as opposed to "bad mothers" (i.e., those who neglected their children's futures). Moreover, education was a pathway to interpersonal worth, possible upward economic mobility, and strong marriage prospects.

All of these motivations are observed in the case of Om Ismail. Om Ismail laughed nervously when she told me she had nine children. Later, she explained that she always preempts what she thinks others are thinking: that she is a stereotype, a low-income woman with too many kids. Om Ismail described calling a child help hotline that was advertised for "children in need." She told them that she had nine children and that she needed help supporting them. They sent her a food basket. "What am I going to do with one food basket?" She wanted to be able to educate them, she told me, so as to not be seen as a woman who had nine children who "threw them in the street."

It was this feeling that motivated her insistence on sending them to school. When her oldest son, Ismail-who was also working in the tannery, picking up discarded ligaments from the process that are used to make glue-failed two classes, Om Ismail was devastated. The teacher told her that she would need to pay 200 EGP for a private lesson so he could retake the classes. Ismail's father did not want to pay, citing the needs of their other children. However, Om Ismail insisted. She rustled up the funds by borrowing from a neighbor. By the end of the summer, Ismail was promoted to the 10th grade. "I want him to be something," she told me. This same statement, word for word, was repeated by Badreya, who said, "Education is the most important thing. I do not want my child to become a mechanic's assistant. Even if we do not eat, I will pay for the fees. I want him to be something."

This "something" had a few different meanings. One was to be competitive on the labor market. Despite the fact that the low quality of schools meant that there

\footnotetext{
${ }^{8}$ The deviance of bribing a janitor is another manifestation of a dysfunctional system.
} 
was a mismatch between the labor market and educational skills (Assaad and Roudi-Fahimi 2007), mothers had few options to make their children competitive. Indeed, education as a labor market tool can be thought of as an aspirational purchase. It is buying a ticket into the chance to work one's way out of the slum (Beckert 2011).

Second, having an education also had a moral value of being perceived as not ignorant (Frye 2012). As was shown with the case of Gamalat in the previous section, who valued education for her girls, Om Ismail described her feeling of shame at not having gotten an education:

I want them to be better, to raise us up, to not be like me. I sit with my cousins and they talk about things and I have no idea what they are saying a lot of the time, and they say, "Well, that's because you're ignorant," and I am. I do not want my kids to be ignorant like me.

Finally, education also had meaning for marriage market prospects. Om Ayman, Om Ismail's neighbor, for instance, finished a technical high school as did her husband. While she worked for a few years as a seamstress's assistant, her husband was chronically unemployed. Despite the fact that neither one of them worked with their credentials, Om Ayman was proud of the fact that she had an education. She held out hope that her husband would get a white-collar desk job, asking me if I would look over his résumé for a job fair that was occurring that summer. Om Ayman and her husband were married because their education made them a "good fit." Om Ismail and her husband, alternatively, could not hope to secure anything but low-skilled work. While Om Ayman and Om Ismail knew first- and secondhand that education could lead to underemployment, they still valued its pursuit.

In all of these examples, mothers chose to manage the high cost of Egypt's lowquality public education because education was meaningful to them and because its meaning outweighed its economic cost in their eyes. Indeed, while the conditions of the CCT assumed that mothers needed an incentive to invest in their children, mothers' commitment to education may be irrational in pure economic estimates given the limited returns the system promises. It was also incredibly costly, requiring difficult, challenging work on the part of these households.

\section{Earmarking Within the Household}

To clarify the economic cost of these educational fees and the crucial place of the CCT cash in confronting those fees, it is important to consider what other resources were available within these households. Indeed, on average, families spent approximately $50 \%$ of what they spent on food on this educational expense. This amount is substantial given the extent of household poverty. How do mothers manage to set aside or earmark cash for this expense in the context of scarcity? I argue that the origin of the income, coupled with the value mothers assign to education, enables earmarking for this expense. However, in dire situations, other demands put on household monies break these earmarks.

The survey conducted with all 156 CCT participants in 2009 displayed the scarcity of resources in the hands of these respondents. Men's work was poorly paid 
and irregular, as was employment for the $38 \%(n=60)$ of women who were income earners. ${ }^{9}$ No one had a regular job with a contract. Seventy-four percent $(n=83)$ of women with employed spouses received "allowance" usually in the form of daily cash, although this money was also irregular. Twenty-five percent $(n=21)$ of these women reported that conflicts between spouses affected the amount of allowance received. Older male children, and sometimes welfare money, supported widows and divorcées who made up 25\% $(\mathrm{n}=39)$ of the total sample. At the time of the survey, $66 \%(n=103)$ of the women were currently in debt to a friend or family member, an NGO (for a microcredit loan), or an informal vendor who sold wares door to door on installments. Women also reported participation in rotational savings groups. Moreover, interviews with the families clarified that children also worked. While due to its illicit nature this did not show up in the survey, from the interviews I found that of the 60 school-aged children in this sample, at least 15 worked: in grocery stores, as hairdressers and janitors, and in the tannery. ${ }^{10}$

From these resources, women scrimped and saved to pay the expense imposed by the educational system. However, household gender norms shaped the extent to which different household resources could be used by the mothers. For example, although Fawzeya, a mother of three, was helping her husband sell cleaning products in the market, she did not know how much he made from the business. Instead, she received a weekly allowance. This opacity of household finances negates the concept of money's fungibility and clarifies that who earns the cash shapes how money enters the home. While Collins et al. (2009) would log her husband's income as a family resource, it was not. Arguments about money were a constant between the couple. They increased as their eldest child had entered the final and most expensive stage of secondary school. When Fawzeya failed to secure extra money from her husband to pay for lessons and study groups, she borrowed from her neighbors. Fawzeya's husband was not responsible for returning the money she borrowed, because borrowing was deemed "women's work," a task humiliating for men.

And even when women entered the labor market, they navigated cultural meanings around their labor. Nagwa, a resident of the Iwaa, along with her sisterin-law, worked cleaning houses (as did 11\% of the working women in this sample). While Nagwa admitted that she would take any job that her religion permitted, she stipulated that the job be far from where she lived. "Here, women taunt us," she claimed, "saying you who work this or that when they argue with us, making fun of our work. It's hurtful for us and also for the kids." Moreover, Nagwa did not speak to her husband about her work for fear of upsetting his pride. In a reversal of the norm of allowance, Nagwa gave her husband cigarette money: "A box of cigarettes for the man keeps us from a lot of crap." Nagwa's husband's lack of work meant that she was responsible for household expenses, including her daughter's study group and private lesson fees.

9 This number was $41 \%$ after the CCT in 2011 , because some women used that income to start small businesses.

10 This is despite laws precluding children under 16 from working and under 18 from working hazardous jobs. 
In this context of precarious work and lack of control within the household, the CCT money was a crucial resource to confronting child education expenses. While this study has shown that the condition was unnecessary, the fact that the cash was disbursed through a program that aimed to improve child education morally marked this money, assisting women in safeguarding it against other uses in the household. This alludes to the potential benefit of labels in context of economic scarcity, as observed in the Moroccan CCT trial (Benhassine et al. 2013). Moreover, the fact that the cash was transferred to mothers and that it was a regular assistance mattered for these women who had few other regular resources and who did not have full control over household resources.

Fawzeya, for instance, described the CCT money as a "buffer," which reduced her need to ask her husband for study group and lesson fees. Similarly, when she was receiving the CCT, Nagwa was able to make good on the cost of her daughter's lessons. However, after the program stopped in 2011, Nagwa found herself more likely to skip payments - that is, if she saw that her daughter had a grasp of the material - and less likely to offer her a daily allowance to buy food if she was hungry at school. While Nagwa contemplated taking her daughter out of school due to her other expenses, she emphasized the importance of education, "particularly for girls," she said. Indeed, for Nagwa, Fawzeya, and the other women in this study, like Noor, whose income came from three different odd jobs, or Om Ismail, who relied on her husband's allowance, this cash stood out as a reliable resource in the context of the uncertainty that informed their poverty. This reliability was best summarized by Dina, who said,

our expenses are so high, and we live from day to day... The best thing about the $200 \mathrm{EGP}^{11}$ per month is not that it was much cash but that it was regular and received at the beginning of the month.... For day laborers at God's mercy, the most important day is the first day of the month. If I know some money is coming, I can borrow against that amount.

Another morally marked cash in the household was children's earnings. Even though child labor was illegal in Egypt, many of the children in this study earned money to help their families. For example, Nada, a 16-year-old girl, worked in the tannery with her 19-year-old sister. Similarly, Om Ismail's three boys (all under the age of 14) worked sifting through the discards of the tannery for ligaments used to make glue. Indeed, for the same reason that mothers valued education, they felt uncomfortable with their children's employment. When Om Ismail told her neighbor, Om Ayman, that her husband wanted to keep Ismail home from school after he failed, Om Ayman responded, "Work and no education? That's so unfair!" Studies show that child labor negatively impacts their school enrollment (Assaad, Levison, and Zibani 2010). Given the low quality of the educational system, however, and the costs imposed, the role of child work may be more complicated.

Finally, in this context of heightened need, even earmarked money from the CCT or child's work was sometimes "misspent." Although Nada's mother initially claimed that she earmarked income for her own education, through my continued relationship with the family, I recognized that the mother depended on a portion of

11 The CCT amount began as 200 EGP and later increased to 250 EGP. 
Nada's income for daily expenses including rent and food. This was particularly the case when Nada's older sister (who also worked with her in the tannery) was preparing her trousseau for marriage and her older brother was preparing for his own wedding. And while Om Ismail earmarked her children's income to pay the cost of their private lessons, study groups, and their pocket money, she had not paid for several of Ismail's lessons that year. Her husband's back trouble-the result of an on-the-job injury that he had not gotten compensation for despite a drawn-out court case - coupled with the costs of having to move apartments resulted in her need for their income. She attributed Ismail's failure in school to her own "misuse" of his earnings. The three boys remained enrolled in school, however, as Om Ismail refused to have them drop out - fighting with Ismail and his father. There were also cases where the CCT cash could not be used to pay for schools. For instance, Om Ayman, Om Ismail's neighbor, used it to pay rent under the threat of eviction. And although Dina used the cash to keep Sarah and her younger son in school, when her husband's medical needs were not covered by public health care, she used this cash to pay those expenses.

In short, a commitment to child education, and earmarking money toward this expense, is only possible to a certain extent, given the high health burdens and constant experience of poverty in these households. It was for this reason that the CCT cash, despite its conditions, was useful in its regularity. Mothers knew that they could count on this money at the beginning of each month, given few other regular incomes. Thus, while the condition was unnecessary, the cash, given to women and marked for education through the program, was a crucial resource in confronting this expense given the fact of Egypt's low-quality education services.

\section{CONCLUSION}

This article shows that exclusively observing outcomes of a program can blackbox causal mechanisms. While policy makers have long called for mixed-methods approaches, these are often inductive, asking whether impacts are met, rather than ethnographic, asking how individuals manage. Moreover, the "gold standard" remains large-scale experiments-randomized control trials. While these can tell you what average outcomes are for interventions, they cannot tell you how the intervention works in the lives of recipients.

In this case, it was a CCT program pilot intended to incentivize mothers to send their children to school. Mothers did send their children to school as a result of this program. However, it was not because of an incentive. Delving into the lives of these mothers through a qualitative approach, I showed that mothers trying to send their children to school must pay to do so in the Egyptian case, due to the low quality of education. And mothers have always paid, even though they have scarce resources to confront this expense. It was the CCT cash, then, and not the conditions, that mattered for meeting the goal of child education. Mothers did not need an incentive. In fact, their commitment to education, and their management of this expense, was the reason that children remained enrolled in school at all, before, during, or after the program. Thus, while the conditions were superfluous, the cash- 
transferred to mothers and labeled for education-was a crucial resource for sending children to school in the context of scarcity.

This Egyptian story contributes to the three central debates around CCTs. First, CCT programs assume that child outcomes are a result of a lack of performance of a human capital generating behavior. Therefore, the solution to improving child outcomes is to incentivize different behavior (Fiszbein and Schady 2009; Lomelí 2008). Through this case of low-income Egyptian mothers, this study contributes to the argument that poverty is often structurally imposed rather than individually done (Katz 2013). In the Egyptian case, it is clear that low-income mothers do want to send their children to school, but the obstacle of the quality of the institution hampers this goal. Qualitative methodologies are well suited to examining why individuals behave the way they do, clarifying individual reasons, and preventing assumptions that result in inefficient policies (Small, Harding, and Lamont 2010; Tilly 2006).

Second, while critics of CCTs argue that they force women to work for development by transferring the cash to them (Molyneux 2006), and proponents argue that these programs are "empowering" (Adato et al. 2000), I argue that the CCT is neither in the Egyptian case. Mothers are the ones who are responsible for child education, with or without the program, and transferring this cash to them facilitates this task. However, the cash does not empower them, as household inequalities and their disenfranchised relationship to the state remain unchanged (Kabeer 1999).

Finally, CCT programs assume that the conditioned services are in fact free, quality institutions; or if they are low quality, that conditioning access to these services will increase demand and therefore accountability (Fiszbein and Schady 2009; Lomelí 2008). However, in the case of Egypt, the demand is there, but the institution remains subpar because individuals lack the social capital or political power to change its function. While CCTs are presented as "efficient" policy tools, the efficiency of a demand-side intervention versus a supply-side intervention is unclear in this case where the educational services require substantial reform (Handa and Davis 2006). While investment in development is ideally not a zero-sum game, the assumption that the bridge to school enrollment should be built on the demand side may divert attention from development of the supply.

Due to the mismatch between CCT assumptions and the on-the-ground reality in the Egyptian case, while the CCT money did facilitate child access to school in Ain EsSira, it was because it facilitated mothers' ability to pay for child education. As a result, the CCT had the unintended consequence of contributing to a corrupt system. As these programs continue to be implemented internationally, and as a national program is being implemented in Egypt, this article highlights the importance of country-specific programing (Rodrik 2008) and qualitative checks on quantitative impact evaluations (Adato 2008), which pay attention to the contextual considerations of users. For the Egyptian case, where mothers do want to educate children, a short-term solution to immediate need is unconditional cash transfers for education, but a long-term solution necessitates substantial supply-side reform. Moreover, it is important that these demand-side interventions do not detract resources from the necessary supply-side overhaul. 


\section{REFERENCES}

Adato, Michelle. 2008. "Combining Survey and Ethnographic Methods to Improve Evaluation of Conditional Cash Transfer Programs." International Journal of Multiple Research Approaches 2: 2: 222-236. https://doi.org/10.5172/mra.455.2.2.222.

Adato, Michelle, Bénédicte de la Brière, Dubravka Mindek, and Agnes Quisumbing. 2000. The Impact of PROGRESA on Women's Status and Intrahousehold Relations. Washington, DC: International Food Policy Research Institute.

Adato, Michelle, and John Hoddinott. 2007. Conditional Cash Transfer Programs a "Magic Bullet" for Reducing Poverty?. Washington, DC: International Food Policy Research Institute.

Akresh, Richard, Damien De Walque, Harounan Kazianga, D. De Walque, and Harounan Kazianga. 2013. "Cash Transfers and Child Schooling: Evidence from a Randomized Evaluation of the Role of Conditionality." World Bank Policy Research Working Paper (6340):1-49.

Assaad, Ragui. 2006. "Institutions, Household Decisions, and Economic Growth in Egypt." Contributions to Economic Analysis 278: 385-411. https://doi.org/10.1016/S0573-8555(06)78013-0.

Assaad, Ragui and Asmaa El-Badawy. 2007. "Private and Group Tutoring in Egypt: Where Is the Gender Inequality?” Economic Research Forum Working Paper, Giza, Egypt.

Assaad, Ragui, and Caroline Krafft. 2015. "Is Free Basic Education in Egypt a Reality or a Myth?" International Journal of Educational Development 45: 16-30. https://doi.org/10.1016/j.ijedudev.2015.09.001.

Assaad, Ragui, Deborah Levison, and Nadia Zibani. 2010. "The Effect of Domestic Work on Girls' Schooling: Evidence From Egypt." Feminist Economics 16: 1: 79-128. https://doi.org/10.1080/ 13545700903382729.

Assaad, Ragui, and Farzaneh Roudi-Fahimi. 2007. Youth in MENA: Demographic Opportunity or Challenge?. Washington, DC: Population Reference Bureau.

Baird, Sarah, Francisco H.G. Ferreira, Berk Özler, and Michael Woolcock. 2014. "Conditional, Unconditional and Everything in Between: A Systematic Review of the Effects of Cash Transfer Programmes on Schooling Outcomes." Journal of Development Effectiveness 6: 1: 1-43. https://doi.org/10.1080/ 19439342.2014.890362.

Baird, Sarah J., Richard S. Garfein, Craig T. McIntosh, and Berk Özler. 2012. "Effect of a Cash Transfer Programme for Schooling on Prevalence of HIV and Herpes Simplex Type 2 in Malawi: A Cluster Randomised Trial." The Lancet 379: 9823: 1320-1329. https://doi.org/10.1016/S0140-6736(11)617091.

Balabanova, Dina, and Martin McKee. 2002. "Understanding Informal Payments for Health Care: The Example of Bulgaria." Health Policy 62: 3: 243-273. https://doi.org/10.1016/S0168-8510(02)00035-0.

Bandelj, Nina. 2012. "Relational Work and Economic Sociology." Politics \& Society 40: 2: 175-201. https://doi.org/10.1177/0032329212441597.

Beckert, Jens. 2011. "The Transcending Power of Goods: Imaginative Value in the Economy." In J. Beckert and P. Aspers, eds., The Worth of Goods: pp. 106-128. Oxford: Oxford University Press.

Benhassine, Najy, Florencia Devoto, Esther Duflo, Pascaline Dupas, and Victor Pouliquen. 2013. Turning a Shove Into a Nudge? A "Labeled Cash Transfer" for Education. Cambridge, MA: National Bureau of Economic Research.

Bertrand, Marianne, Sendhil Mullainathan, and Eldar Shafir. 2004. "A Behavioral-Economics View of Poverty." The American Economic Review 94: 2: 419-423. https://doi.org/10.1257/0002828041302019.

Chant, Sylvia. 2008. "The 'Feminisation of Poverty' and the 'Feminisation' of Anti-Poverty Programmes: Room for Revision?” The Journal of Development Studies 44: 2: 165-197. https://doi.org/10.1080/ 00220380701789810.

Collins, Daryl, Jonathan Morduch, Stuart Rutherford, and Orlanda Ruthven. 2009. Portfolios of the Poor: How the World's Poor Live on \$2 a Day. Princeton, NJ: Princeton University Press.

Demographic and Health Surveys (DHS). 2008. "Net School Attendance Rate by Quintile." STATcompiler. Retrieved June 12, 2017 (http://www.statcompiler.com/en/)

Duneier, Mitchell. 2011. "How Not to Lie With Ethnography." Sociological Methodology 41: 1: 1-11. https://doi.org/10.1111/j.1467-9531.2011.01249.x.

Elbadawy, Asmaa. 2013. "The Effect of Tutoring on Secondary Streaming in Egypt." Economic Research Forum Working Paper, Giza, Egypt.

Elbadawy, Asmaa. 2015. "Education in Egypt: Improvements in Attainment, Problems With Quality and Inequality." In R. Assaad, ed., The Egyptian Labor Market in an Era of Revolution: pp. 127-148. Oxford: Oxford University Press.

England, Paula. 2010. "The Gender Revolution Uneven and Stalled." Gender and Society 24: 2: 149-166. https://doi.org/10.1177/0891243210361475. 
Espeland, Wendy Nelson, and Mitchell L. Stevens. 1998. "Commensuration as a Social Process." Annual Review of Sociology 24: 313-343. https://doi.org/10.1146/annurev.soc.24.1.313.

Fahim, Yasmine, and Noha Sami. 2010. "Access to and Equity in Financing Higher Education in Egypt.” In A. Galal and T. Kanaan, eds., Financing Higher Education in Arab Countries: pp. 11-28. Cairo: Economic Research Forum.

Fiszbein, Ariel, and Norbert Schady. 2009. Conditional Cash Transfers: Reducing Present and Future Poverty. Washington, DC: World Bank.

Frye, Margaret. 2012. "Bright Futures in Malawi’s New Dawn: Educational Aspirations as Assertions of Identity." American Journal of Sociology 117: 6: 1565-1624. https://doi.org/10.1086/664542.

Galiani, Sebastian, and Patrick J. McEwan. 2013. "The Heterogeneous Impact of Conditional Cash Transfers.” Journal of Public Economics 103: 85-96. https://doi.org/10.1016/j.jpubeco.2013.04.004.

Garcia, Sandra, and Jennifer Hill. 2010. "Impact of Conditional Cash Transfers on Children's School Achievement: Evidence from Colombia." Journal of Development Effectiveness 2: 1: 117-137. https://d oi.org/10.1080/19439341003628681.

Gertler, Paul J., Sebastian Martinez, Patrick Premand, Laura B. Rawlings, and Christel M.J. Vermeersch. 2011. Impact Evaluation in Practice. Washington, DC: World Bank.

Grant, Ruth W. 2011. Strings Attached: Untangling the Ethics of Incentives. Princeton, NJ: Princeton University Press.

Handa, Sudhanshu, and Benjamin Davis. 2006. "The Experience of Conditional Cash Transfers in Latin America and the Caribbean." Development Policy Review 24: 5: 513-536. https://doi.org/10.1111/j. 1467-7679.2006.00345.x.

Handoussa, Heba. 2008. Egypt Human Development Report 2008, Egypt's Social Contract: The Role of Civil Society. Cairo: United Nations Development Programme.

Handoussa, Heba. 2010. Youth in Egypt: Building Our Future, Egypt Human Development Report 2010. Cairo: United Nations Development Programme.

Hanushek, Eric A. and Ludger Wößmann. 2007. "The Role of Education Quality for Economic Growth.” World Bank Policy Research Working Paper, Washington DC.

Herrera, Linda. 1992. Scenes of Schooling : Inside a Girls' School in Cairo. Cairo: American University in Cairo Press.

Herrera, Linda. 2003. "Participation in School Upgrading: Gender, Class and (In)action in Egypt." International Journal of Educational Development 23: 2: 187-199. https://doi.org/10.1016/S0738-0593(02) 00013-5.

Herrera, Linda, and Carlos Alberto Torres. 2006. "Introduction: Possibilities for Critical Education in the Arab World." In L. Herrera and C.A. Torres, eds., Cultures of Arab Schooling Critical Ethnographies From Egypt: pp. 1-24. Albany: State University of New York Press.

Hoodfar, Homa. 1997. Between Marriage and the Market: Intimate Politics and Survival in Cairo. Berkeley: University of California Press.

Ille, Sebastian. 2015. "Private Tutoring in Egypt: Quality Education in a Deadlock Between Low Income, Status and Motivation." ECES Working Paper no. 178, Cairo.

Imai, Kosuke, Dustin Tingley, and Teppei Yamamoto. 2013. "Experimental Designs for Identifying Causal Mechanisms." Journal of the Royal Statistical Society. Series A: Statistics in Society 176: 1: 5-51. https://doi.org/10.5172/mra.455.2.2.222.

Kabeer, Naila. 1999. "Resources, Agency, Achievements: Reflections on the Measurement of Women's Empowerment." Development and Change 30: 3: 435-464. https://doi.org/10.1111/1467-7660.00125.

Kahneman, Daniel. 1994. "New Challenges to the Rationality Assumption." Journal of Institutional and Theoretical Economics 150: 1: 18-36. Retrieved January 25, 2018 (http:/www.jstor.org/stable/ 40753012)

Kandil, Radwa. 2011. "The Egyptian Education System and Public Participation." Social Policy 41: 2: 58-64.

Katz, Michael. 2013. The Undeserving Poor: America's Enduring Confrontation With Poverty: Fully Updated and Revised. Oxford: Oxford University Press.

Lomelí, Enrique Valencia. 2008. "Conditional Cash Transfers as Social Policy in Latin America: An Assessment of Their Contributions and Limitations." Annual Review of Sociology 34: 475-499. https://doi.org/10.1146/annurev.soc.34.040507.134537.

Loveluck, Louisa. 2012. "Education in Egypt: Key Challenges." Background Paper 16, Middle East and North Africa Programme, Chatham House, London.

Mitchell, Timothy. 2002. Rule of Experts: Egypt, Techno-Politics, Modernity. Berkeley: University of California Press.

Molyneux, Maxine. 2006. "Mothers at the Service of the New Poverty Agenda: Progresa/Oportunidades, Mexico's Conditional Transfer Programme." Social Policy and Administration 40: 4: 425-449. https://doi.org/10.1111/j.1467-9515.2006.00497.x. 
Olson, John F., Corinna Preuschoff, Ebru Erberber, Alka Arora, and Joseph Galia. 2007. "TIMSS International Mathematics Report." Lynch School of Education, Boston College.

Portes, Alejandro and Lori D. Smith. 2012. Institutions Count: Their Role and Significance in Latin American Development. Berkeley: University of California Press.

Post, David. 1981. "The Massification of Education in Hong Kong: Effects on the Equality of Opportunity, 1981-1991." Sociological Perspectives 39: 1: 155-174. https://doi.org/10.2307/1389347.

Rashwan, Nada Hussein. 2011. "Teachers' Strike Reaches Unprecedented Heights in March on the Cabinet." Ahram Online, November 14. Retrieved January 24, 2018 (http:/english.ahram.org.eg/ NewsContent/1/64/22374/Egypt/Politics-/Teachers-strike-reaches-unprecedented-heights-in-m.aspx)

Riccio, J., N. Dechausay, C. Miller, S. Nuñez, and N. Verma. 2013. Conditional Cash Transfers in New York City: The Continuing Story of the Opportunity NYC-Family Rewards Demonstration. New York: MDRC.

Rodrik, Dani. 2008. One Economics, Many Recipes: Globalization, Institutions, and Economic Growth. Princeton, NJ: Princeton University Press.

Rutherford, Bruce. 2008. Egypt After Mubarak: Liberalism, Islam, and Democracy in the Arab World. Princeton, NJ: Princeton University Press.

Sayed, Eman and Ray Langsten. 2014. "Gender, Tutoring and Track in Egyptian Education." World Academy of Science, Engineering, and Technology, International Journal of Social, Behavioral, Educational, Economic, Business, and Industrial Engineering 8: 10: 3215-3219. https://doi.org/10.1999/1307$6892 / 9999498$.

Schwab, Klaus. 2014. The Global Competitiveness Report. Cologny, Switzerland: World Economic Forum.

Singerman, Dianne. 1995. Avenues of Participation: Family, Politics, and Networks in Urban Quarters of Cairo. Princeton, NJ: Princeton University Press.

Small, Mario Luis, David J. Harding, and Michele Lamont. 2010. "Reconsidering Culture and Poverty." The Annals of the American Academy 629: 6-27. https://doi.org/10.1177/0002716210362077.

Soares, Fábio Veras, Rafael Perez Ribas, and Rafael Guerreiro Osório. 2010. "Evaluating the Impact of Brazil's Bolsa Família: Cash Transfer Programs in Comparative Perspective." Latin American Research Review 45: 2: 173-190. Retrieved January 25, 2018 (http://www.jstor.org/stable/27919200)

Sobhy, Hania. 2012. "The De Facto Privatization of Secondary Education in Egypt: A Study of Private Tutoring in Technical and General Schools." Compare: A Journal of Comparative and International 42: 1: 47-67. https://doi.org/10.1080/03057925.2011.629042.

Tadros, Mariz. 2006. "State Welfare in Egypt since Adjustment: Hegemonic Control With a Minimalist Role." Review of African Political Economy 33: 108: 237-254. https://doi.org/10.1080/ 03056240600842701 .

Thaler, Richard H. 1999. "Mental Accounting Matters." Journal of Behavioral Decision Making 12: 3 : 183-206. https://doi.org/10.1002/(SICI)1099-0771(199909)12:3 < 183:AID-BDM318 > 3.0.CO;2-F.

Thaler, Richard, and Cass Sunstein. 2009. Nudge: Improving Decisions About Health, Wealth, and Happiness. New York: Penguin.

Tilly, Charles. 2006. Why? What Happens When People Give Reasons. . and Why. Princeton, NJ: Princeton University Press.

UNESCO. 2005. Guidelines for Inclusion: Ensuring Access to Education for All. Retrieved January 24 , 2018 (http://unesdoc.unesco.org/images/0014/001402/140224e.pdf)

Weinbaum, Marvin G. 1985. "Egypt's Infitah and the Politics of U.S. Economic Assistance." Middle Eastern Studies 21: 2: 206-222. https://doi.org/10.1080/00263208508700624.

World Bank. 2015. World Development Indicators. Washington, DC: World Bank.

Zelizer, Viviana A. 1996. "Payments and Social Ties." Sociological Forum 11: 3: 481-495. Retrieved January 24, 2018 (http://www.jstor.org/stable/684897)

Zelizer, Viviana A. 1997. The Social Meaning of Money. Princeton, NJ: Princeton University Press.

Zelizer, Viviana A. 2012. "How I Became a Relational Economic Sociologist and What Does That Mean?" Politics \& Society 40: 2: 145-174. https://doi.org/10.1177/0032329212441591. 